\title{
Fruit and Vegetable Consumption in Relation to Nutritional Status of Women of Childbearing Age in Yogyakarta City
}

\author{
Hastin Dyah Kusumawardani ${ }^{1}$, Suryati Kumorowulan ${ }^{2}$ \\ \{hastin_dk@yahoo.com ${ }^{1}$ \} \\ Balitbangkes Magelang, Magelang, Indonesia ${ }^{1,2}$
}

\begin{abstract}
Riskesdas 2018 reported that less fruit and vegetable consumption to people in the age of more than 5 years reached 95.5 percent. Meanwhile the number of over weight gain and obesity keep increasing to 35.4 percent. In 2018, the number of obesity in Yogyakarta City is 26.9 percent, higher than the total number nationally. Fruit and vegetables consumption is one of the way to fill the balanced nutritious, maintain health and keep the body weight. This study is a cross-sectional research to the Women of Childbearing Age aged 15-50 years old in Yogyakarta City. The total sample is 234 women. The measured variables are body weight, body height, and food frequency. Result In this research, there are 6,7 percent thin women, 42,5 percent in normal weight, 33,3 percent in over weight and 17,5 percent in obesity. Based on the chi square test result, it is found that there is a significant relationship $(0,009<0.05)$ between fruit consumption and nutritional status meanwhile the vegetable consumption has no significant relationship $(0,301>0.05)$ with the nutritional status. There ia a significant relationship $(0,003<0,005)$ between vegetable consumption and age. Conclusion The fruit consumption has a significant relationship to the nutritional status and significant relationship between vegetable consumption and nutritional status of Women of Childbearing Age in Yogyakarta City.
\end{abstract}

Keywords: Fruit and vegetables consumption, nutritional status, women of childbearing age

\section{Introduction}

Nowadays, in Indonesia there are multiple nutrition problems, which is still found the lack of nutrition or stunting, and the increasing over nutrition problems. Over nutrition occurs to people in the age more than 18 years old reaching 13.6 percent and obesity reaches 21.8 percent [1]. Obesity is more likely related to the unbalanced intake and released energy. Moreover, it is explained that obesity is related to age, gender, economic status, job, biscuit and bread eating habit, and smoking habit [2]. The long-term impact of overweight and obesity is the increasing risk of incidence of non-communicable diseases such as diabetes mellitus, hypertension, and heart disease [3].

The increasing prevalency of non-communicable disease in Indonesia, is affected to the improvement of health public service by both community and the state. This is inseparable from the change into the less active lifestyle and the change of food consumption containing high 
sugar and low fiber. Riskesdas 2018 stated that the low prevalency of fruit and vegetable consumption in people older than 5 years old reached 95.5 percent. Fruit and vegetable contains fiber, vitamin and mineral that cannot be found in other food products. Nutritional content that is in fruit and vegetable potentially maintains body weight from obesity and overweight [1], [4]. Meanwhile, the recommended fruit consumption that can help to prevent chronic disease is about 400-600 grams per day [5].

Unprocessed fruit contains lower energy and higher fiber affected to the increased satiety and delay hunger [4]. Study towards high school students shows that the habit of fruit and vegetable consumption is affected by media exposure, nutrition knowledge, and parent's opinion [5]. In line with this study, a study in China reported that an increase in fruit and vegetable consumption in adult males is inversely related to body weight, and in adult females there occurs covering effect to the disease since there is an increase of fruit and vegetable consumption [6]. Meanwhile, on children with asthma, consumption of fruit, nuts and green vegetables and root are related significantly to the weight loss [7].

Riskesdas 2018 stated that the prevalency of obesity in Yogyakarta City is 26.9 percent higher that the number in national level which is 21.8 percent, based on gender, women suffer from non-communicable diseases (1,78 percent) than men. Based on age, the age group 15-64 years has a greater prevalence contracting non-communicable diseases $(11,52$ percent) than other age groups [1]. This condition need attention because it is related to the increasing number of non-communicable diseases so it needs further study about the factors related to the obesity condition such as the habit of consuming fruit and vegetable. The purpose of this study is to know the relation of fruit and vegetable consumption to the nutritional status woman of childbearing age in Yogyakarta City.

\section{Methods}

The design of the research is a cross sectional study with samples of women of childbearing age around 15-50 years old. The total sample is 234 women. The collected data includes age, anthropometry which is body weight and height and the habit of food consuming especially fruits and vegetables. The data is a part of a study entitled Relation of Iodine Status to the Thyroid Function in Yogyakarta City, Purworejo Regency and Bukittinggi City [8].

The age data is gained by counting the respondents age based on the date of born, the data of body height is counted by using microtoise, the data of body weight is gained by measuring the respondents body weight by using AND brand digital scales with accuracy of 0.1 gram, data of nutritional status is gained by counting IMT based on the body height and body weight, data of dietary pattern is gained by using food frequency questionnaire semi quantitative which there is a habit of consuming fruits and vegetables. The gained data then is processed by using Chi Square test.

\section{Results and Discussion}

\subsection{Results}

The counting result of nutritional status based on the body mass index can be known that there is 21 percent obesity lower than Riskesdas result in 2018. Overweight in women of 
childbearing age in this study is still high, which is 33,3 percent. The data of nutritional status can be seen in Figure 1.

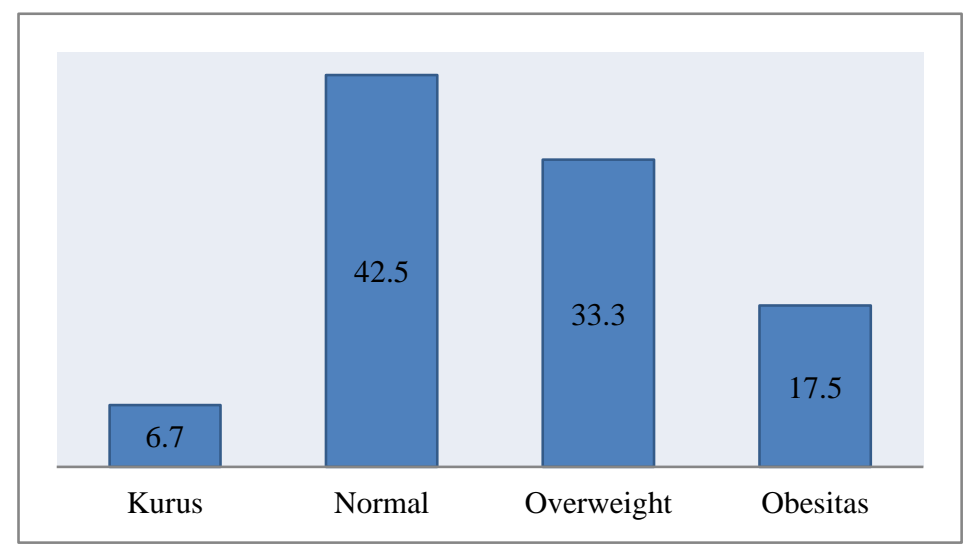

Fig. 1. Nutritional Status of Women of Childbearing Age

In this research, the respondents who often consume fruit are 31.2 percent than consuming vegetable (29.5 percent), meanwhile the respondents who always consume fruit are 22.2 percent than consuming vegetable (21.4 percent). The respondent's data of fruit and vegetable consumption completely is in Table 1 and 2.

Table 1. Relationship between Vegetable Consumption and Nutritional Status on the Woman of Childbearing Age

\begin{tabular}{llllll}
\hline Nutritional & Vegetables & & & $p$ \\
\cline { 2 - 5 } Status & Rarely/Never & Sometimes & Often & Always & \\
\hline Thin & 2 & 5 & 1 & 4 & 0,301 \\
Normal & 27 & 20 & 33 & 22 & \\
Overweight & 22 & 16 & 22 & 15 & \\
Obesity & 7 & 16 & 13 & 9 & \\
\hline
\end{tabular}

Table 2. Relationship between Fruits Consumption and Nutritional Status on the Woman of Childbearing Age

\begin{tabular}{llllll}
\hline Nutritional & Fruits & & & & $p$ \\
\cline { 2 - 5 } Status & Rarely/Never & Sometimes & Often & Always & \\
\hline Thin & 2 & 3 & 5 & 2 & 0,009 \\
Normal & 17 & 38 & 32 & 15 & \\
Overweight & 8 & 16 & 27 & 24 & \\
Obesity & 15 & 10 & 9 & 11 & \\
\hline
\end{tabular}

Based on the chi square analysis result, vegetable consumption is not related to the nutritional status $(p>0.05)$, meanwhile the fruit consumption is significantly related to the nutritional status $(\mathrm{p}<0.05)$. Vegetable consumption is significantly related to the respondent's age $(\mathrm{p}<0.05)$, while fruit consumption is not significantly related to the respondent's age $(\mathrm{p}>0.05)$. Respondents who always consume vegetable are mostly found in the age group $>40$ 
years old which is 8.6 percent. While the respondents who rarely/never consume vegetable are found in the age group of 31-40 years old is 11.9 percent. Fruit and vegetable consumption based on the age group in woman of childbearing age show in Table 3.

Table 3. Fruit and Vegetable Consumption based on the age group in Woman of Childbearing Age

\begin{tabular}{lllllllll}
\hline & \multicolumn{2}{c}{$\mathbf{2 0}$ years old } & \multicolumn{2}{c}{$\mathbf{2 1 - 3 0}$ years old } & $\mathbf{3 1 - 4 0}$ & years old & \multicolumn{2}{c}{ >40 years old } \\
\cline { 2 - 10 } & $\begin{array}{l}\text { Fruit } \\
(\%)\end{array}$ & $\begin{array}{l}\text { Vegetable } \\
(\%)\end{array}$ & $\begin{array}{l}\text { Fruit } \\
(\%)\end{array}$ & $\begin{array}{l}\text { Vegetable } \\
(\%)\end{array}$ & $\begin{array}{l}\text { Fruit } \\
(\%)\end{array}$ & $\begin{array}{l}\text { Vegetable } \\
(\%)\end{array}$ & $\begin{array}{l}\text { Fruit } \\
(\%)\end{array}$ & $\begin{array}{l}\text { Vegetable } \\
(\%)\end{array}$ \\
\hline Rarely/Never & 2.2 & 4.9 & 3.8 & 1.1 & 6.5 & 11.9 & 5.9 & 9.7 \\
Sometimes & 3.8 & 1.1 & 4.3 & 4.9 & 6.5 & 8.6 & 12.4 & 9.2 \\
Often & 1.6 & 0.5 & 5.4 & 5.4 & 13.0 & 8.1 & 11.4 & 12.4 \\
Always & 1.1 & 2.2 & 1.6 & 3.8 & 10.3 & 7.6 & 10.3 & 8.6 \\
\hline
\end{tabular}

\subsection{Discussion}

Overweight and obesity in Yogyakarta City in this research reach 33.3 percent and 17,5 percent. The obesity prevalency in this study is lower that the number in Riskesdas 2018. Along with this study, another researcher stated that the obesity is higher happened in city than in countryside. It is related to the citizen lifestyle who tend to eat fast food, lack of activity due to a sedentary lifestyle, use electronic equipment, and vehicle [2]. Other researchers also stated the similar thing that overweight in city is higher (27.02 percent) that overweight in countryside (18.48 percent). Overweight is mostly found more in women than men [9]. The body composition of females has more fat than muscles. The fat composition of females is 6-11 percent more than males. Females also have hormone estrogen so it tends to keep and maintain fat [10]. The weakness in this result is not doing the determinant factors analysis from the obesity such as obesity history in the past, physical activity, and other factors.

Fruit and vegetable is an important component of balanced nutrition that can be used as the primary food or even snacks. Fruit and vegetable contains vitamin, mineral, fiber and other photochemistry component that is beneficial to the body. Increasing fruit and vegetable consumption is a good way to optimize health and prevent chronic disease [11]. In this study, the fruit consumption is significantly related to the nutritional status of woman in fertile age, while consuming vegetables is not related. The weakness of this study is not counting the fiber intake from consumed vegetable and fruit so it is unknown whether the fiber intake in consumed vegetable and fruit is different or not. Fiber content in fruit will be dispersed into water, and form gel that is used to slow gastric emptying. Besides that, fermented fiber in the digestive tract will help the metabolism of carbohydrate and fat [12]. Other researcher stated that consuming fruit daily give less risk of being overweight 1.99 times lower than not consuming fruit, and have 2.49 lower risk of being obesity than not consuming fruit [2].

Along with this research, a study in Europe reported that there is an inverted relation between women weight gain with the consumption of fruit, vegetable, food sources of fiber and whole wheat [13]. Different result reported by other researcher, that consuming fruit and vegetable in adult women does not show any relationship with overweight level, caused by the few amounts of fiber consumption from fruit and vegetable [14]. Weight loss and keep the body weight to not gain done by decreasing energy intake, increasing energy output, and level out the fat stock. Having a habit of consuming fruit, vegetables, seeds and nuts that contain vitamin, mineral, and beneficial fiber to help weight loss and help maintaining the body weight. So, it does not only decrease the energy intake, but also, we should choose the food product with lower energy density like fruit and vegetable [12]. 
This research reported that consuming vegetable is significantly related to the respondent's age. The respondent's prevalency that is often and always consuming vegetables is higher in the age of more than 30 years old. Along with the research, other researcher reported that the proportion of citizen consuming vegetable more is in the adult group [15]. Supporting the result of this research, the study in Yogyakarta City about the habit of eating fruit and vegetable in teen age stated that the teenagers consume less vegetable with some reasons like the plain taste, the habit of consuming fast food as it is more practical and highly parent's opinion that the can buy various kinds of food based on their preference [16].

\section{Conclusion}

Consuming fruit is significantly related to the nutritional status of fertile age women, and consuming vegetable is also significantly related to the fertile age women in Yogyakarta City.

\section{References}

[1] Kementerian Kesehatan. Hasil Utama Riskesdas 2018. Badan Penelitian dan Pengembangan Kesehatan. 2018

[2] Sudikno, Syarief H, Dwiriani CM, Riyadi H. Faktor resiko overweight dan obese pada orang dewasa di Indonesia. Gizi Indon. 2015; 38(2): 91-104

[3] Lee YS, So JBY, Deurenberg-Yap M. Confronting the Obesity Epidemic: Call to Arms. Annals Academy of Medicine. 2009; 38(1)

[4] Tetens I, Alinia S. The role of fruit consumption in the prevention of obesity. Journal of Horticultural Science \& Biotechnology. 2009; Special Issue: 47-51

[5] Rachman BN, Mustika IG, Kusumawati IGA. Faktor yang berhubungan dengan perilaku konsumsi buah dan sayur siswa SMP di Denpasar. Jurnal Gizi Indonesia. 2017; 6(1): 9-16

[6] Yuan S, Yu HJ, Liu MW, Huang Y, Yang XH, Tang BW, Song Y, Cao ZK, Wu HJ, He QQ, Gasevic $D$. The association of fruit and vegetable consumption with changes in weight and body mass index in Chinese adults: a cohort study. Public Health. 2018; 1(157): 121-126

[7] Wall CR, Stewart AW, Hancox RJ, Murphy R, Braithwaite I, Beasley R, Mitchell EA. Association between frequency of consumption of fruit, vegetables, nuts and pulses and BMI: analysis of the international study of asthma and allergies in childhood. Nutrients. 2018; 10(316): 1-11

[8] Kumorowulan S, Wahyuningrum SN, Kusrini I, Sukandar PB, Kusumawardani HD, Riyanto S, Prihatmi EB, Sudarinah, Mulyani D, Astuti BD, Janah NA. Hubungan status iodium dengan fungsi tiroid di Kota Yogyakarta, Kabupaten Purworejo, dan Kota Bukitinggi. Media Gizi Mikro Indonesia. 2019; 11(1): 15-24

[9] Kencana S, Nurillah A. Hubungan faktor sosial demografi dan kegemukan pada penduduk dewasa di Indonesia tahun 2007 dan 2010. Jurnal Ekologi Kesehatan. 2014; 13(4): 328-339

[10] Tan AKG, Dun RA, Samad MIA. Sociodemographic and health lifecycle determinants of obesity risk in Malaysia. Asia Pacific Journal of Public Health. 2011;23(2): 192-202

[11] Mobasheri M, Tavassoli E, Ramezankhani A, Mirmiran P, Mehrabis Y, Alidosti M, Khaledifar A. Improvment of consumption of fruits and vegetables aimed at the prevention of obesity in girl students. Life Science Journal. 2014; 11(9): 454-458

[12] Requena MC, Gonzales CNA, Barragan LA, Cunha MG, Correia MT, Esquivel JC, Herrera RR. Dietary Fiber: an ingredient againts obesity. Emirates Journal of Food and Agriculture. 2016; 28(8): 522-530

[13] Buijsse B, Feskens EJM, Schulze MB, Forouhi NG. Wareham NJ, Sharp S, Palli D, Tognon G, Halkjaer J, Tjonneland A. Fruit and vegetable intakes and subsequent changes in body weight in 
European population: result from the project on diet, obesity, and genes. Am J Clin Nutr. 2009; 90: 202-209

[14] Diana R, Yuliana I, Yasmin G, Hardinsyah. Faktor risiko kegemukan pada wanita dewasa Indonesia. Jurnal Gizi dan Pangan. 2013; 8(1): 1-8

[15] Hermina, Prihatini S. Gambaran konsumsi sayur dan buah penduduk Indonesia dalam konteks gizi seimbang: analisis lanjut survei konsumsi makanan individu (SKMI) 2014. Buletin Penelitian Kesehatan. 2016; 44(3): 205-218

[16] Oktavia AR, Syafiq A, Setiarini A. Faktor-faktor yang berhubungan dengan konsumsi buah-sayur pada remaja di daerah rural-urban, Yogyakarta. Jurnal Keperawatan Raflesia. 2019; 1(1): 33-44 